\title{
Leukoplakia of the urinary bladder: keratinising squamous metaplasia
}

\author{
Tushar Pandey, ${ }^{1}$ Siddharth Pandey, ${ }^{2}$ Apul Goel, ${ }^{2}$ Ajay Aggarwal ${ }^{2}$
}

'Department of Pathology, Post Graduate Institute of Medical Education and Research, Chandigarh, India ${ }^{2}$ Department of Urology, King George's Medical University, Lucknow, Uttar Pradesh, India

\section{Correspondence to} Dr Siddharth Pandey, sid1420@gmail.com

Accepted 15 August 2018

\section{DESCRIPTION}

A 22-year-old man presented with gross haematuria for 7 days. He had a history of voiding lower urinary tract symptoms since undergoing surgery for spinal injury he sustained 2 years previously. On cystoscopy, he had cystitic changes in the entire urinary bladder along with bladder clots that were subsequently evacuated (figure 1). He also had whitish plaques near both the ureteric orifices (figure 2). The mucosa underneath the plaques was inflamed and bled on manipulation. The efflux from both ureteric orifices was normal. Random bladder biopsies were taken. His urine culture was positive for Escherichia coli, and he was given cultureguided antibiotics. A contrast enhanced computed tomography (CECT) scan was done which showed thickened bladder walls with normal upper urinary tracts. Histopathological examination revealed keratinising squamous metaplasia of the urinary bladder (figure 3). On further evaluation, he was diagnosed with neurogenic bladder and was advised clean intermittent self-catheterisation along with annual cystoscopic monitoring to look for any malignant changes.

Keratinising squamous metaplasia is rarely encountered in urological practice with an incidence of 1:10000. In areas where schistosomiasis is uncommon, it usually occurs due to chronic irritation of the inflamed bladder mucosa by bacteria. The risk factors include chronic catheterisation, neurogenic bladder, vitamin A deficiency, urinary fistulas and bladder outlet obstruction. ${ }^{1}$

The presenting symptoms of this condition are non-specific and include urgency, frequency, dysuria and haematuria. Our patient had gross haematuria with bladder clots. Usually on keratinising squamous metaplasia, it is white in colour

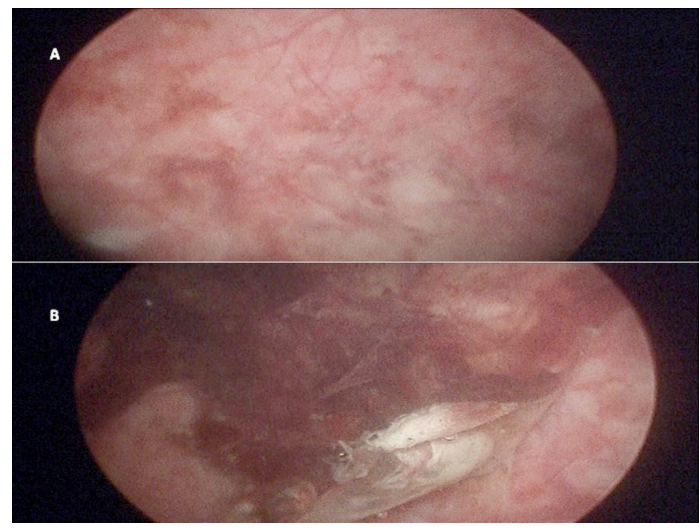

Figure 1 Cystoscopic image of cystitic changes in urinary bladder (A) and the bladder clots (B).

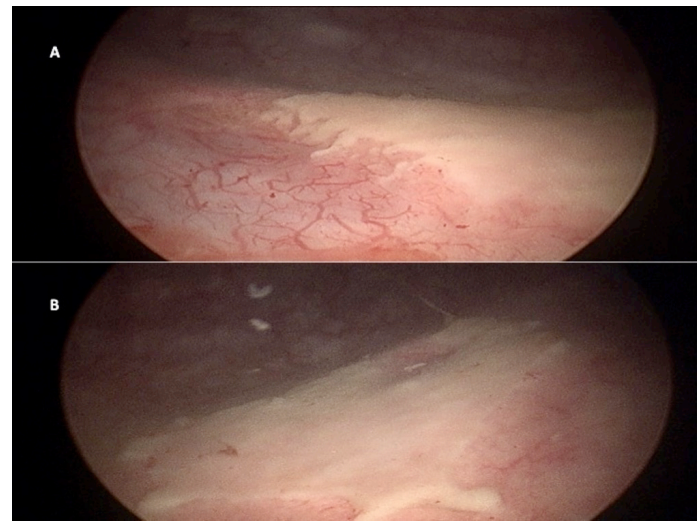

Figure 2 Cystoscopic image of the whitish plaques near right $(A)$ and left (B) ureteric orifices.

but pigmented patches have also been reported that may make a clinical diagnosis difficult. ${ }^{2}$ Microscopically, the normal urothelium is replaced by squamous epithelium with an overlying layer of keratin. A biopsy is required to confirm the diagnosis and differentiate it from malakoplakia, fungal cystitis and amyloidosis. There have been reports of keratinising squamous metaplasia progressing to squamous cell carcinoma or having concurrent squamous cell carcinoma. Due to the rarity of this lesion, there is paucity of level-1 evidence proving it to be a premalignant condition, but based on available literature close monitoring with annual cystoscopy is advised as a grade- $\mathrm{C}$ recommendation. ${ }^{3}$

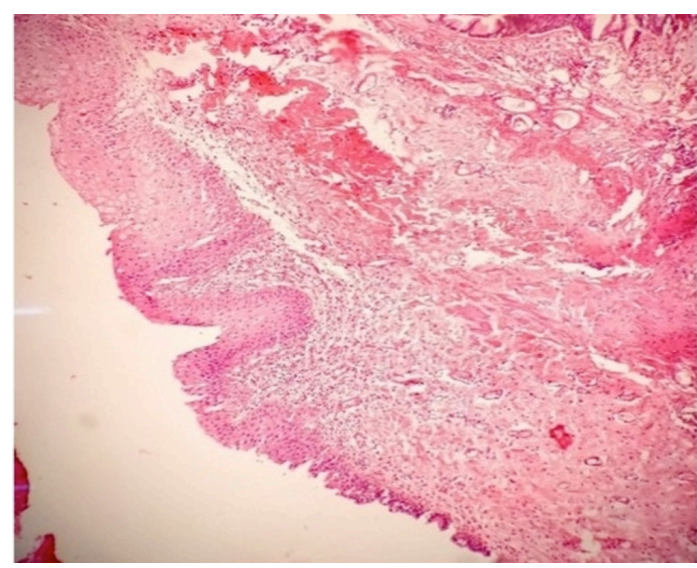

Figure 3 Photomicrograph at $\times 10$ magnification of biopsy from bladder mucosa under the plaque showing the metaplastic keratinised squamous epithelium on the top left, the transition to urothelium can be seen on the bottom right, along with this there is oedema and inflammatory infiltrates in the submucosa. 


\section{Learning points}

Keratinising squamous metaplasia of the urinary bladder is a rare condition that occurs due to chronic irritation of urinary bladder usually by bacteria, and predisposing conditions include neurogenic bladder, chronic catheterisation, vitamin A deficiency, urinary fistulas and bladder outlet obstruction.

- Based on available literature, the current recommendation is for close cystoscopic monitoring annually to look for any subsequent malignant changes.

Contributors SP conceived the case report. SP and TP were major contributors towards writing the manuscript. AG, AA and SP treated the patient and also interpreted the patient data. SP and AG were involved in the review. All authors read and approved the final manuscript.

Funding The authors have not declared a specific grant for this research from any funding agency in the public, commercial or not-for-profit sectors.

Competing interests None declared.

Patient consent Obtained.

Provenance and peer review Not commissioned; externally peer reviewed.

\section{REFERENCES}

1 Khan MS, Thornhill JA, Gaffney E, et al. Keratinising squamous metaplasia of the bladder: natural history and rationalization of management based on review of 54 years experience. Eur Urol 2002;42:469-74.

2 Batura D, Mitsopoulos G. Keratinising cystitis with intestinal metaplasia following a Crohn's vesico-intestinal fistula. Int Urol Nephrol 2015;47:803-4.

3 Amin MB, McKenney JK, Paner GP, et al. ICUD-EAU International consultation on bladder cancer 2012: pathology. Eur Urol 2013;63:16-35.

Copyright 2018 BMJ Publishing Group. All rights reserved. For permission to reuse any of this content visit http://group.bmj.com/group/rights-licensing/permissions.

BMJ Case Report Fellows may re-use this article for personal use and teaching without any further permission.

Become a Fellow of BMJ Case Reports today and you can:

- Submit as many cases as you like

- Enjoy fast sympathetic peer review and rapid publication of accepted articles

- Access all the published articles

Re-use any of the published material for personal use and teaching without further permission

For information on Institutional Fellowships contact consortiasales@bmjgroup.com

Visit casereports.bmj.com for more articles like this and to become a Fellow 